\title{
TRIBUTE TO JORDI MARIA DE GIBERT ATIENZA
}

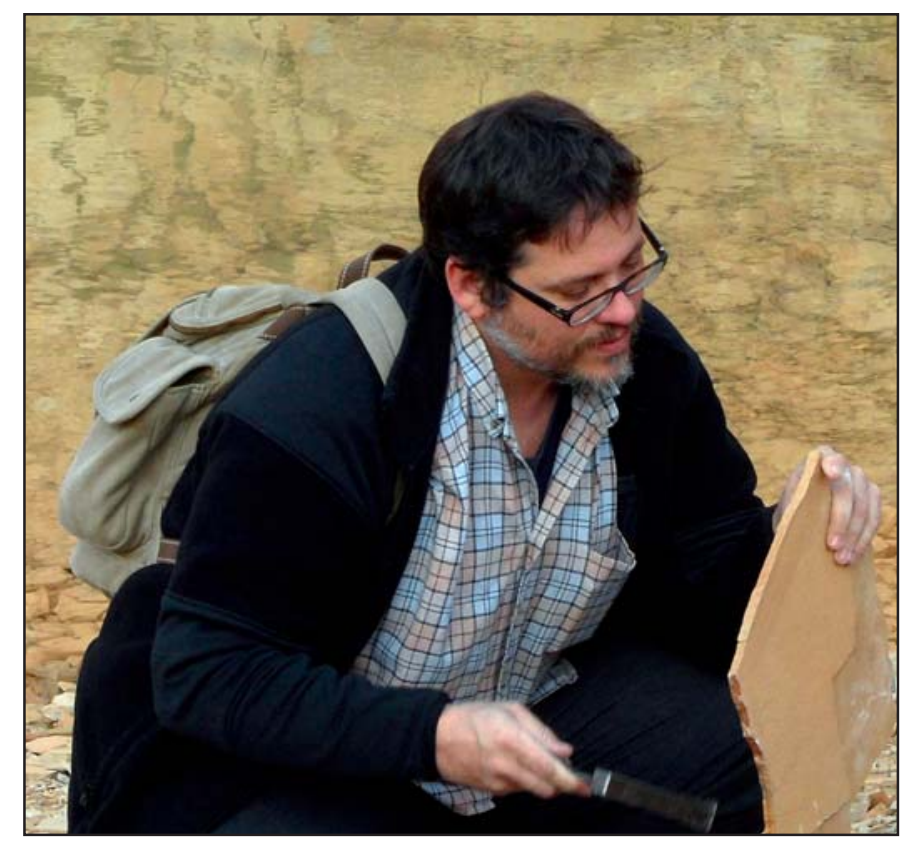

Guest co-editors

Rosa Domènech Arnal

Dept. Estratigrafia, Paleontologia i Geociències Marines

Univ. Barcelona

Allan A. Ekdale

Dept. Geology and Geophysics, Univ. Utah

José A. Gámez Vintaned

Dept. Geosciences, Univ. Teknologi Petronas

Jordi Martinell Callicó

Dept. Estratigrafia, Paleontologia i Geociències Marines

Univ. Barcelona 


\section{JORDI MARIA DE GIBERT ATIENZA}

On September 23rd 2012, Jordi Maria de Gibert Atienza, an innovative explorer of the fossil record, passed away suddenly in Barcelona. He left behind interesting scientific contributions in the areas of invertebrate ecology, palaeoecology, evolutionary ecology, taphonomy and ichnology. Jordi Maria was only 44 and had a whole life in science ahead of him. The 2014 volume of the Spanish Journal of Palaeontology is dedicated to his memory.

Born in 1968 in Barcelona, Jordi Maria completed his undergraduate studies at the Geology Faculty of the University of Barcelona. Since adolescence he had liked fossils, and often visited palaeontological sites. He quickly developed a special interest in trilobites; of which he possessed a small collection. Once his university education was finished, Jordi Maria joined the research group "Palaeobiology of the Mediterranean Neogene" also at the Universitat de Barcelona, and set aside his affection for trilobites to delve deeper into the field of ichnology. He had been a student of palaeontology under two of us (JM and RD); which is how he got started in the fields of invertebrate palaeontology and ichnology. He obtained his $\mathrm{PhD}$ in 1996 with a thesis on Neogene trace fossils (supervised by JM). During his period as a graduate student, Jordi Maria had several short stays with R. Goldring (University of Reading, England), who became his instructor on bioturbation. As a young postdoctoral researcher, Jordi Maria spent three highly formative years at the University of Utah with another of us (AAE). Together, we witnessed Jordi Maria progress from a promising pupil to a valued colleague and collaborator.

The academic contribution of Jordi Maria sums 94 papers published in several different journals, almost all of them included in international indexes. He also made a total of 99 contributions at national and international conferences. One of the highlights of his scientific production is the diversity of colleagues he worked with around the world. This comes as no surprise, since Jordi Maria was always a very easygoing person with a great interest in languages who loved human relationships, cultural diversity and travel to remote places.

Jordi Maria's contributions to science would surely have been different, or would not have occurred at all, without his special ability to connect disjoint elements and create synergies; which he did not only in the field of palaeontology. He was a man who kept an open mind, and was willing to help but also able to ask for help when he needed it. The relationships he forged with many of his co-workers went beyond palaeontology, spanning varied interests (literature, music, film, sports) and encompassing curiosity about the world and beyond. We see now that perhaps he was in a hurry to live.

Jordi's published work covers many different aspects of animal-sediment interrelationships in the areas of palaeobiology and sedimentology. He offered detailed descriptions of fish trace fossils, lacustrine ichnocoenoses, echinoid ichnofabrics, crustacean burrows and worm borings in fossil whale bones. He presented thoughtful interpretations of salinity controls of ichnofacies in the Mesozoic of Utah and substrate controls of ichnofacies in the Cenozoic of Spain. He philosophized about behavioural evolution throughout the trace fossil record. He named several new ichnotaxa (e.g., Sinusichnus sinuosus); he made a major contribution to erecting a new ethological category (Fixichnia) for superficial etching scars on hard substrates; and he worked towards establishing a new ichnofacies (Entobia Ichnofacies) for the recurrent trace fossil associations in rocky shore palaeoenvironments. He wrote several papers that incorporate ichnological data with sequence stratigraphic interpretations and palaeoclimatic reconstructions.

Jordi ably served the worldwide ichnological community by establishing and managing the "Skolithos" listserver to facilitate informal communication between ichnologists. But he also needed to communicate his research to a wider public; in fact, to the whole of society that makes science possible. The blog "Infaunal Epiphany" was his last step along this route, but he really only had enough time to publish the foundational ideas.

He was one of the hard-working organizers of several seminal research conferences in Spain, including the Bioerosion Workshop and the Taphonomy Workshop in Barcelona in 2000 and 2005, respectively; the Crustacean Ichnology Workshop in Lepe in 2010; and the International Ichnofabric Workshop in Colunga in 2011. 
Jordi Maria also collaborated in more technical, though not for that less necessary, aspects of science. Among other activities, he was co-founder and treasurer of the International Ichnological Association (IIA), scientific adviser to the private museum CosmoCaixa, member of the Institute for Research of Biodiversity (IRBio, University of Barcelona), and Earth Sciences coordinator of the Spanish Agency for Evaluation and Forecasting (ANEP, Spanish Ministry of Economy and Competitiveness). Jordi Maria worked particularly hard for six years as treasurer of the Spanish Palaeontological Society. He was also on the editorial boards of several learned journals, notably: Butlletí de la Institució Catalana d'Història Natural, Geologica Acta and Ichnos. It was a telling sign of his character that he almost never refused to review a manuscript for other journals, and often became deeply involved.

Those of us who were close to Jordi Maria will without a doubt also remember him as an excellent teacher. For some thirteen years, he taught undergraduate geology and postgraduate palaeontology at the University of Barcelona. He participated both in palaeontological and in geological mapping courses, interacting most effectively with students and stimulating their curiosity about science. He made time to supervise some undergraduate and master's degree projects, as well as undertaking the great research project of the PhD thesis of Zain Belaústegui. Moreover, the faculty remembers him as an efficient and charismatic secretary of the geology studies council; a position he held for his last three years.

To close, we wish to thank the authors and reviewers of the manuscripts that appear here for their kind and generous contribution to this volume dedicated to Jordi Maria's memory. The contributions are from around the world and cover several different aspects of ichnology; something that we are sure would have pleased Jordi Maria. 
